\title{
Oxidation-Resistant Reflective Surfaces for Solar Dynamic Power Generation in Near Earth Orbit
}

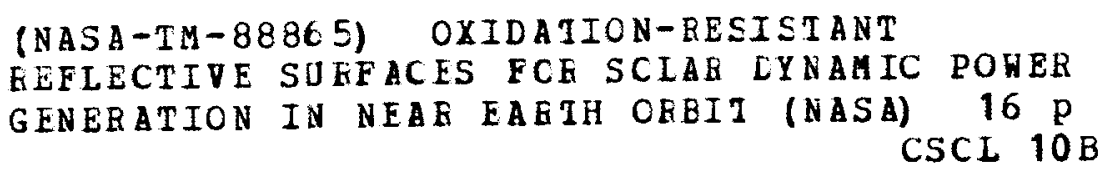

Daniel A. Gulino

Lewis Research Center

Cleveland, Ohio

Robert A. Egger

Cleveland State University

Cleveland, Ohio

and

William F. Banholzer

General Electric Company

Schenectady, New York

Prepared for the 33rd National Symposium of the National Vacuum Society Baltimore, Maryland, October 27-31, 1986

\section{Nush}


Trade names or manufacturers' names are used in this report for identification only. This usage does not constitute an official endorsement, either expressed or implied, by the National Aeronautics and Space Administration. 


\title{
OXIDATION-RESISTANT REFLECTIVE SURFACES FOR SOLAR DYNAMIC POWER
}

\section{GENERATION IN NEAR EARTH ORBIT}

\author{
Daniel A. Gulino \\ National Aeronautics and Space Administration \\ Lewis Research Center \\ Cleveland, Ohio 44735 \\ Robert A. Egger \\ Cleveland State University \\ Cleveland, Ohio 44115 \\ and \\ William F. Banholzer \\ General Electric Company \\ Corporate Research and Development \\ Schenectaúy, New York 12309
}

\begin{abstract}
Reflective surfaces for Space Station power generation systems are required to withstand the atomic oxygen-dominated environment of near earth orbit. Thin films of platinum and rhodium, which are corrosion resistant reflective metals, have been deposited by fon beam sputter deposition onto various substrate materials. Solar reflectances were then measured as a function of time of exposure to a rf-generated air plasma. Similarly, various protective coating materials, including $\mathrm{MgF}_{2}, \mathrm{SiO}_{2}, \mathrm{Al}_{2} \mathrm{O}_{3}$, and $\mathrm{Si}_{3} \mathrm{~N}_{4}$, were deposited onto silver-coated substrates and then exposed to the plasma. Analysis of the films both before and after exposure by both ESCA and Auger spectroscopy was also performed. The results indicate that $\mathrm{Pt}$ and $\mathrm{Rh}$ do not suffer any loss in reflectance over the duration of the tests. Also, each of the coating materials survived the plasma environment. The ESCA and Auger analyses are discussed as well.
\end{abstract}

\section{INTRODUCTION}

In the current proposed initial operating configuration (IOC) for Space Station, electrical power will be generated by a combination of both 
photovoltaic (PV) and solar dynamic (SD) systems, with PV providing 33 percent and SO providing 67 percent of the total power generated. Photovoltaic systems have long been used to provide electrical power for a variety of spacecraft. Solar dynamic systems, to date, have never been flown in space. However, the Space Station presents several new challenges and requirements for which a solar dynamic system may be better suited.

A solar dynamic system generates electricity by focusing the sun's light, either by reflecting mirrors or refracting lenses, onto the receiver of a heat engine. Such a system has the potential to be more efficient than a PV system. Hence, the solar collector area can be smaller for a given amount of power generation, or, conversely, more power can be generated for a given collector area.

The IOC requires a bus power of $75 \mathrm{~kW}$, which is approximately a factor of three greater than any power system previously flown. A PV array based on current silicon solar cell technology would have to be quite large to meet this power requirement, perhaps to the point of being unwieldy, especially if it is desired to increase the generating capacity as the Space station grows. In addition, a 7 to $10 \mathrm{yr}$ lifetime is required from the various components which comprise the power generation system. This could be a significant problem, considering the harshness of the low earth orbit environment through which Space Station will orbit.

The LEO environment is a hostile one toward the survivability of spacecraft component materials. At altitudes of $180 \mathrm{~km}(97 \mathrm{nmi})$ to $650 \mathrm{~km}$ (350 nmi) atomic oxygen is the most abundant species (Ref. 1). This is a highly reactive and corrosive species whose effect on materials flown aboard orbiting spacecraft is well documented (Refs. 2 to 4 ). In a solar dynamic system, the effect of atomic oxygen on the reflecting surfaces is a major 
concern. There are two potential solutions to this problem. The first is to use a corrosion-resistant metal, such as platinum or rhodium, as the reflecting medium. Since these metals are not as reflective as silver, a penalty would be paid in reduced efficiency of the system. The second potential solution is to use a protective coating to prevent atomic oxygen from reaching the silver layer.

Any material used as a protective coating against atomic oxygen degradation for reflector surfaces must meet two requirements. The material must be resistant to oxidation, and it must be transparent. Because the mirror surface will be on a rigid substrate, flexibllity of the protective coating is not a demanding requirement.

It was the intent of the work to be described here to investigate several materials, including magnesium fluoride $\left(\mathrm{MgF}_{2}\right)$, aluminum oxide $\left(\mathrm{Al}_{2} \mathrm{O}_{3}\right)$, silicon dioxide $\left(\mathrm{SiO}_{2}\right)$, and silicon nitride $\left(\mathrm{Si}_{3} \mathrm{~N}_{4}\right)$ for potential use as protective coatings on silver mirrors. A variety of materials, including aluminum, graphite-epoxy composite, electroformed nickel, and beryllium-copper alloy were used as substrates. Resistance to atomic oxygen attack was characterized by observing changes in integrated solar reflectance as a function of time of exposure to a laboratory-generated, oxygen plasma environment. While it is difficult to derive a direct relationship between lifetime in the simulated environment and lifetime in LEO, use of the laboratory facility does allow gross determination of the likelihood of survivability of a particular material in LEO. In addition, samples were examined by both ESCA and Auger electron spectroscopy.

\section{APPARATUS AND PROCEDURE}

All films, including both the reflective and protective layers, were deposited by ion beam sputter deposition using an ion source operated with argon in a deposition facility described elsewhere (Ref. 5). The various 
reflective materials ( $\mathrm{Ag}, \mathrm{Pt}, \mathrm{Rh})$ and protective materials $\left(\mathrm{MgF}_{2}, \mathrm{Al}_{2} \mathrm{O}_{3}, \mathrm{SiO}_{2}\right.$, $\left.\mathrm{Si}_{3} \mathrm{~N}_{4}\right)$ were sputtered from targets $12.7 \mathrm{~cm}$ in diameter and $0.64 \mathrm{~cm}$ thick.

The substrate materials were obtained from several sources and their preparation prior to sputtering depended upon the condition in which they were received. The aluminum, which was 5086 alloy $0.16 \mathrm{~cm}$ thick, was cut into $2.54 \mathrm{~cm}$ squares and polished to a mirror finish using 600 grit paper and then 3 um diamond paste. The graphite-epoxy composite was fabricated by the Materials and Structures Laboratory at NASA Lewis. It consisted of Union Carbide T-300 fibers in a Fiberite 934 epoxy matrix. It was then cut into $2.54 \mathrm{~cm}$ squares and polished lightly with the 600 grit paper. Smooth surfaces were difficult to obtain with this composite system, and no attempt was made to attain an optically flat surface. The electroformed nickel was obtained from Optical Radiation Corp. as $5.08 \mathrm{~cm}$ diameter, $0.15 \mathrm{~cm}$ thick wafers polished on one side. These were cut into quarters and used without further preparation. The beryllium-copper was purchased from Brush-Welliman as an alloy of 2 percent beryllium and 98 percent copper in a roll $2.54 \mathrm{~cm}$ wide and $6.09 \mathrm{~m}(20 \mathrm{ft})$ long. It also was cut into $2.54 \mathrm{~cm}$ squares and polished to a mirror. finish with 600 grit paper and $3 \mu \mathrm{m}$ diamond paste.

The atomic oxygen environment was simulated using a Structure Probe, Inc. Plasma Prep II plasma reactor. In this device, the plasma is created by passing a carrier gas (in this case, ambient air) over the samples and exciting the gas molecules with $100 \mathrm{~W}$ of continuous wave $\mathrm{rf}$ power at $13.56 \mathrm{MHz}$. The operating pressure was about $50 \mu \mathrm{m}$.

Reflectance measurements were made on a Perkin-Elmer Lambda-9 UV/VIS/NIR spectrophotometer equipped with a $60 \mathrm{~mm}$ integrating sphere coated with barium sulfate. To determine the integrated solar reflectance, the specular and total reflectances were first obtained relative to a barium sulfate reference over the wavelength range of 200 to $2500 \mathrm{~nm}$. In using this wavelength range, 
less than 5 percent of the solar spectrum is neglected. These spectra were then processed by first correcting the spectra for the reflectance of the reference (Ref. 6) and then convoluting the spectra into the air-mass-zero (AMO) solar spectrum (Ref. 7) over the same wavelength range according to the following expression (Ref. 8):

$$
\bar{\rho}=\frac{\int_{\lambda_{1}}^{\lambda_{2}} \rho(\lambda) Q(\lambda) a(\lambda)}{\int_{\lambda_{1}}^{\lambda_{2}} Q(\lambda) a(\lambda)}
$$

In this equation, $\bar{\rho}$ is the integrated solar reflectance (specular or tota1), $\rho(\lambda)$ is the reflectance (specular or total) at wavelength $\lambda, Q(\lambda)$ is the AMO intensity at wavelength $\lambda_{1} \lambda_{1}=200 \mathrm{~nm}$ and $\lambda_{2}=2500 \mathrm{~nm}$.

$X$-ray photoelectron spectroscopic (XPS) analysis was performed in a Surface Science Laboratories SSX-100 ESCA. Monochromatic Al Ka radiation. was used and was focused to produce a spot size of either 300 or $600 \mu \mathrm{m}$. The pass energy on the hemispherical analyzer was set to $50 \mathrm{eV}$, providing a resolution of $0.8 \mathrm{eV}$ for the $\mathrm{Au} 4 \mathrm{f}_{7 / 2}$ 1ine. The energy scale was calibrated to provide $\mathrm{Cu} 2 \mathrm{p}_{3 / 2}=932.67 \mathrm{eV}$ and the $\mathrm{Au} 4 \mathrm{f}_{7 / 2}=83.98 \mathrm{eV}$. Subsurface layers were examined by removing material using a Kratos "Mini Beam" ion gun. Sputtering was accomplished using $5 \mathrm{keV}$ argon ions with a beam flux of $25 \mu \mathrm{A} / \mathrm{cm}^{2}$.

Auger analysis was performed in a Phf 545 Scanning Auger Microprobe. Auger spectra were acquired using a $5 \mathrm{keV}$ primary beam and a $300 \mathrm{nA}$ beam current. Depth profiles were obtained with a differentially pumped ion gun using argon ions with an incident energy of $2 \mathrm{keV}$. Calibration of the ion gun under these conditions gave a sputtering rate of $100 \mathrm{~A} / \mathrm{min}$ in $\mathrm{SiO}_{2}$.

The normal routine for obtaining reflectance data was as follows: substrates were prepared as described and the reflective metal was then applied. In the case of the platinum and rhodium mirrors, initial reflectances 
were obtained and then the samples were placed in the asher and exposed to the plasma. At periodic intervals, these samples were removed for reflectance measurement and then returned to the asher. In the case of the silver mirrors, protective coatings were applied to the silver surfaces and their reflectances were measured. The samples were then placed in the asher and removed at regular intervals for measurement as described above.

As a basis for comparison, a reflectance fractional loss rate was calculated for each sample by dividing the total reflectance loss by the total hours of exposure. This permitted a direct comparison of the relative atomic oxygen survivability of the various protective-coating/reflective-coating/ substrate systems.

\section{RESULTS AND DISCUSSION \\ Corrosion-Resistant Metais}

Table I shows the results of exposure of unprotected silver, rhodium, and platinum surfaces to the asher plasma environment. Figure 1 shows specular solar reflectance as a function of plasma exposure time for the unprotected sliver sample, the platinum/nickel substrate sample, the rhodium/nickel substrate sample, and the rhodium/beryllium-copper substrate sample.

These data indicate that platinum and rhodium are resistant to the plasma and would not require protective coatings in the LEO environment. The Pt and Rh samples showed negligible reflectance losses over the exposure duration studied here. In one instance a significant reflectance loss was noted for $\mathrm{Rh}$, that of the Rh/beryllium-copper substrate combination, which resulted from apparent spaling of the Rh coating over time. Whether or not this was due to the plasma is not clear and was not investigated further. The absolute reflectance values for Pt and Rh were significantly lower, -prior to exposure, than the value for silver. Such low values would probably preclude the use of 
these metals for solar dynamic reflecting mirrors should a viable coating for silver be found.

The unprotected silver sample showed significant reflectance loss, with a fractional loss rate of factor of about 1000 higher than the Pt and Rh samples. This sample lost about one-third of its reflectance after just $2 \mathrm{hr}$. Clearly a protective coating is required for silver.

\section{Silver with Protective Coatings}

Magnestum fluoride. - Table II shows data indicating the effect of the asher plasma on silver mirror samples with magnesium fluoride protective coatings. In all instances, the coating protected the silver from atomic oxygen attack, and the reflectances were preserved over the exposure duration studied. Reflectance loss rates were negligible. The somewhat lower values of absolute reflectance noted relative to the unprotected silver sample were due to both the imperfect nature of the substrate surfaces and the presence of the $\mathrm{MgF}_{2}$ coating. The effect of the latter can likely be reduced or eliminated by adjusting the thickness of the $\mathrm{MgF}_{2}$ coating. Figure 2 includes a $\mathrm{plot}$ of solar specular reflectance as a function of exposure time of the $\mathrm{MgF}_{2} / \mathrm{Ag} / \mathrm{nickel}$ substrate sample.

ESCA analysis of the magnesium fluoride coatings both before and after exposure showed that the films were substoichiometric, with the approximate ration of $1: 1$ magnesium to fluorine. No effect of the plasma environment was noted.

Silicon dioxide. - Table II shows data for several $510_{2} /$ substrate combinations. The $\mathrm{SiO}_{2}$ coating did protect the silver layer from oxidation, but the reflectance fractional loss rates were generally higher than those for $\mathrm{MgF}_{2}$. $^{-}$

Auger profiling of both unexposed and exposed silicon dioxide coatings indicated a high concentration of carbon (about 30 percent) throughout the 
film. This could be the result of either forward sputtering from the graphite grids used in the ion source or contamination from the hydrocarbon diffusion pump ofl. Ashing of this carbon by the oxygen plasma would give rise to pinholes in the $\mathrm{SiO}_{2} \mathrm{film}$, thus providing a direct pathway for the atomic oxygen to reach the silver surface. It is speculated that if the carbon impurity concentration had been lower (less than 5 percent, see discussion of the $\mathrm{Si}_{3} \mathrm{~N}_{4}$ coatings below), the $\mathrm{SiO}_{2}$-coated sample would have shown no detrimental effects from the oxygen plasma.

Aluminum oxide. - Table II also includes data for several $\mathrm{Al}_{2} \mathrm{O}_{3}$ /substrate combinations. As with the $\mathrm{SiO}_{2}$ and $\mathrm{MgF}_{2}$ coatings, $\mathrm{Al}_{2} \mathrm{O}_{3}$ coatings were successful in preserving the reflectance of sllver mirrors upon exposure to atomic oxygen. As before, reflectance fractional loss rates were very small, ranging to as low as zero for the $\mathrm{Al}_{2} \mathrm{O}_{3} /$ nickel substrate combination, which showed no reflectance loss over the exposure duration studied.

Analysis of an exposed aluminum oxide coating showed no discernable effect of the asher plasma on the coating composition or structure.

Silicon nitride. - Table III shows data for two different thicknesses ( 820 and $2000 \AA$ ) of $\mathrm{Si}_{3} \mathrm{~N}_{4}$ protective coatings. The thinner coating did not adequately protect the silver. Fractional loss rates were generally about an order of magnitude higher that those of the other coatings studied. Figure 2 includes a plot of reflectance versus exposure time for the $\mathrm{Si}_{3} \mathrm{~N}_{4} / \mathrm{nickel}$ substrate combination. As can be seen, the reflectance drops precipitously relative to the $\mathrm{MgF}_{2}$ coating.

In an effort to determine the cause of the observed reflectance losses, a second set of samples was prepared with a considerably thicker $\mathrm{Si}_{3} \mathrm{~N}_{4}$ coating $(2000 \mathrm{~A})$. After exposure to atomic oxygen for a considerable length of time (over $400 \mathrm{hr}$ ), negligible reflectance losses were observed. 
Analysis of these silicon nitride coatings indicated a very high concentration of carbon ( $50 \pm 10$ percent) throughout the $820 \AA \mathrm{film}$ and a low carbon concentration ( $<5$ percent) throughout the $2000 \AA \mathrm{film}$. As was noted in the discussion of the $\mathrm{SiO}_{2}$ films, the high carbon concentration in the thinner film was most likely due to the peculiarities of that particular deposition run. The analysis of the $\mathrm{Si}_{3} \mathrm{~N}_{4}$ film indicated that it is not thickness that determines the effectiveness of the $\mathrm{Si}_{3} \mathrm{~N}_{4}$ film as a protective coating, but the degree of carbon incorporation. Ashing of the small percentage of carbon in the thicker film left no pathway for the atomic oxygen to reach the silver layer. Hence, no reflectance degradation was observed.

Analysis of the $\mathrm{Si}_{3} \mathrm{~N}_{4}$ films also showed that a significant percentage of the $\mathrm{Si}_{3} \mathrm{~N}_{4}$ had been converted to $\mathrm{SiO}_{2}$ upon deposition, and then further conversion occurred during oxygen plasma exposure. After $400+\mathrm{hr}$ of exposure, the 2000 A film had been converted almost completely to $\mathrm{SiO}_{2}$. Since $\mathrm{SiO}_{2}$ is also oxidation resistant, no reflectance degradation would have been expected, and none was observed.

\section{Effect of Substrate}

Samples prepared on graphite-epoxy composite substrates showed solar reflectances that were, in general, lower than those of samples prepared on the other substrate materials. The rough surface morphology of the graphite-epoxy increased the likelihood that defects would be present in the protective coating which could allow the oxygen plasma to reach the silver layer. This problem most likely can be overcome if a sufficiently smooth surface could be obtained on a graphite-epoxy composite.

No effect of substrate on the performance of these coatings could be observed. Even the reflectance losses observed on graphite-epoxy samples were small compared to unprotected silver. Assuming that a smooth surface can be 
obtained on a graphite-epoxy composite, choice of substrate can be made on other grounds, such as cost, handling, weight, durability, etc.

\section{CONCLUSIONS}

While platinum and rhodium survive the atomic oxygen environment, their relatively low solar reflectances (compared to silver) preciude their use in solar dynamic power system reflecting mirrors. If a suitable protective coating for silver can be found, and it appears from the data presented here that this is the case, silver mirrors would be a better choice.

The data presented in this paper indicate that any of the three coating materials of $\mathrm{MgF}_{2}, \mathrm{SiO}_{2}$, and $\mathrm{Al}_{2} \mathrm{O}_{3}$ would perform adequately as a protective coating against atomic oxygen degradation for silver mirror surfaces. Silicon nitride also appears to perform satisfactorily. However, since the $\mathrm{Si}_{3} \mathrm{~N}_{4}$ is essentially completely converted to $\mathrm{SiO}_{2}$, there is no advantage in using the nitride.

In this work, no attempt was made to determine the effect of different desposition techniques on the performance of the protective coatings. For large-scale depositions, techniques other than ion beam sputter deposition are generally more appropriate. Analysis of the atomic oxygen durability of coatings prepared by these other techniques would be useful. 


\section{REFERENCES}

1. U.S. Standard Atmosphere, 1976. (U.S. Government Printing office, Washington, D.C., 1976) p. 30.

2. B.A. Banks, M.J. Mirtich, S.K. Rutledge, and H.K. Nahra. in Proceedings of the 18th IEEE Photovoltaics Specialists Conference. (IEEE, New York, 1985) p. $381-386$.

3. L.L. Leger, "Oxygen Atom Reaction With Shuttle Materials at Orbital A1titudes," AIAA Paper 83-0073, Jan. 1983.

4. A.F. Whitaker, "LEO Atomic Oxygen Effects on Spacecraft Materials," AIAA Paper 83-2632-CF, Nov. 1983.

5. D.A. Gulino, J. Vac. Sci. Technol. A, A4, 509 (1986).

6. F. Grum and G.W. Luckey, Appl. Opt., I, 2289 (1968).

7. H.S. Rauschenbach, Solar Cell Array Design Handbook. (Van NostrandReinhold, New York, 1980) p. 411.

8. M.J. Mirtich and H. Mark, "The Effect of Hypervelocity Projectile Material on the Ultimate Reflectance of Bombarded Polished Metals," NASA TM X-52981, 1971. 
table I. - CHANGE IN SOLAR REFLECTANCE OF UNPROTECTED PLATINUM, RHODIUM,

AND SILVER SURFACES AFTER EXPOSURE TO THE OXYGEN PLASMA ENVIRONMENT

\begin{tabular}{|c|c|c|c|c|c|}
\hline $\begin{array}{l}\text { Reflective } \\
\text { metal }\end{array}$ & Substrate & $\begin{array}{c}\text { Exposure } \\
\text { time, } \\
\text { hr }\end{array}$ & $\begin{array}{l}\text { Infitial solar } \\
\text { reflectance } \\
\text { spec./total }\end{array}$ & $\begin{array}{l}\text { Final solar } \\
\text { reflectance } \\
\text { spec./total }\end{array}$ & $\begin{array}{c}\text { Fractiona } 1 \\
\text { loss per } \\
1000 \mathrm{hr} \\
\text { spec./total } 1\end{array}$ \\
\hline $\mathrm{Ag}$ & Nickel & 2.1 & $0.952 / 0.962$ & $0.6654 / 0.741$ & $142 / 105$ \\
\hline $\begin{array}{l}\mathrm{Rh} \\
\mathrm{Rh} \\
\mathrm{Rh} \\
\mathrm{Rh}\end{array}$ & $\begin{array}{l}\text { Aluminum } \\
\text { Nickel } \\
\text { Bery } 111 \text { um- } \\
\text { copper } \\
\text { Graphite- } \\
\text { epoxy }\end{array}$ & $\stackrel{54.5}{1}$ & $\begin{array}{r}0.656 / .690 \\
.706 / .712 \\
.634 / .665 \\
0.402 \% .634 \\
\end{array}$ & $\begin{array}{r}0.631 / .666 \\
.693 / .700 \\
.418 / .548 \\
.323 / .550\end{array}$ & $\begin{array}{c}0.459 / 0.440 \\
.239 / .220 \\
3.96 / 2.15 \\
1.45 / 1.54\end{array}$ \\
\hline $\begin{array}{l}\mathrm{Pt} \\
\mathrm{Pt} \\
\mathrm{Pt} \\
\mathrm{Pt}\end{array}$ & $\begin{array}{l}\text { Aluminum } \\
\text { Nickel } \\
\text { Beryllium- } \\
\text { copper } \\
\text { Graph'te- } \\
\text { epoxy }\end{array}$ & 39.5 & $\begin{array}{c}0.697 / 0.727 \\
.731 / .736 \\
.697 / .727 \\
\text { d. } 428 / .622\end{array}$ & $\begin{array}{l}0.692 / 0.714 \\
.719 / .724 \\
.685 / .714 \\
.379 / .608\end{array}$ & $\begin{array}{c}0.127 / 0.329 \\
.304 / .304 \\
.304 / .329 \\
1.24 / .354\end{array}$ \\
\hline
\end{tabular}

aThe low reflectance values for these samples were due to the relatively rough graphite-epoxy surface.

TABLE II. - CHANGE IN SOLAR REFLECTANCE OF SILVER MIRRORS WITH VARIOUS PROTECTIVE COATINGS AFTER EXPOSURE TO THE OXYGEN PLASMA ENVIRONMENT

\begin{tabular}{|c|c|c|c|c|c|c|}
\hline $\begin{array}{l}\text { Protective } \\
\text { coating }\end{array}$ & $\begin{array}{c}\text { Coating } \\
\text { thickness, } \\
A\end{array}$ & Substrate & $\begin{array}{c}\text { Exposure } \\
\text { time, } \\
h r\end{array}$ & $\begin{array}{l}\text { Initiai solar } \\
\text { reflectance } \\
\text { spec./total }\end{array}$ & $\begin{array}{l}\text { Final solar } \\
\text { reflectance } \\
\text { spec./ total }\end{array}$ & $\begin{array}{c}\text { Fractional } \\
\text { loss per } \\
1000 \mathrm{hr} \\
\text { spec./total }\end{array}$ \\
\hline $\mathrm{MgF}_{2}$ & $\begin{array}{l}920 \\
900 \\
920 \\
900\end{array}$ & $\begin{array}{l}\text { Aluminum } \\
\text { Nickel } \\
\text { Beryilium- } \\
\text { copper } \\
\text { Graphite- } \\
\text { epoxy }\end{array}$ & $\begin{array}{r}88.5 \\
108.5 \\
88.5 \\
108.5\end{array}$ & $\begin{array}{c}0.838 / 0.882 \\
.899 / .909 \\
.892 / .909 \\
.661 / .828\end{array}$ & $\begin{array}{l}0.823 / 0.870 \\
.886 / .901 \\
.879 / .995 \\
.557 / .730\end{array}$ & $\begin{array}{c}0.169 / 0.136 \\
.120 / .074 \\
.147 / .158 \\
.959 / .903\end{array}$ \\
\hline $510_{2}$ & $\begin{array}{l}400 \\
850 \\
400 \\
850\end{array}$ & $\begin{array}{l}\text { Aluminum } \\
\text { Nickel } \\
\text { Beryilium- } \\
\text { copper } \\
\text { Graphite- } \\
\text { epoxy }\end{array}$ & $\begin{array}{l}62 \\
83 \\
62 \\
83\end{array}$ & $\begin{array}{c}0.866 / 0.898 \\
.883 / .913 \\
.914 / .929 \\
.712 / .837\end{array}$ & $\begin{array}{r}0.761 / 0.791 \\
.807 / .839 \\
.859 / .873 \\
.630 / .785\end{array}$ & $\begin{array}{l}1.69 / 7.72 \\
.910 / .892 \\
.887 / .903 \\
.988 / .627\end{array}$ \\
\hline$A 7_{2} 0_{3}$ & $\begin{array}{l}350 \\
580 \\
350 \\
580\end{array}$ & $\begin{array}{l}\text { Aluminum } \\
\text { Nickel } \\
\text { Beryllium- } \\
\text { copper } \\
\text { Graphite- } \\
\text { epoxy }\end{array}$ & $\begin{array}{l}62 \\
75 \\
62 \\
75\end{array}$ & $\begin{array}{c}0.850 / 0.882 \\
.911 / .920 \\
.866 / .881 \\
.802 / .871\end{array}$ & $\begin{array}{c}0.823 / 0.869 \\
.911 / .920 \\
.779 / .826 \\
.802 / .868\end{array}$ & $\begin{array}{c}0.435 / 0.210 \\
.00 \% .00 \\
1.40 / 8.87 \\
.00 \% .040\end{array}$ \\
\hline
\end{tabular}

TABLE III. - CHANGE IN SOLAR REFLECTANCE OF SILVER MIRRORS WITH SILICON NITRIDE PROTECIIVE COATINGS AFTER EXPOSURE TO THE OXYGEN PLASMA ENVIRONMENT

\begin{tabular}{|c|c|c|c|c|c|}
\hline $\begin{array}{c}\text { Si3N4 } \\
\text { coating } \\
\text { thickness, } \\
A\end{array}$ & Substrate & $\begin{array}{c}\text { Exposure } \\
\text { time. } \\
\text { hes }\end{array}$ & $\begin{array}{l}\text { Initial solar } \\
\text { reflectance } \\
\text { spec./total }\end{array}$ & $\begin{array}{l}\text { Final solar } \\
\text { reflectance } \\
\text { spec./total }\end{array}$ & $\begin{array}{l}\text { Fractional } \\
105 \mathrm{per} \\
1000 \mathrm{hr} \\
\text { spec./total }\end{array}$ \\
\hline 820 & $\begin{array}{l}\text { Aluminum } \\
\text { Nickel } \\
\text { Beryilitum- } \\
\text { copper } \\
\text { Graphite- } \\
\text { epoxy }\end{array}$ & 48.5 & $\begin{array}{c}0.907 / 0.940 \\
.931 / .945 \\
.914 / .936 \\
.309 / .886\end{array}$ & $\begin{array}{l}0.572 / 0.596 \\
.525 / .536 \\
.635 / .651 \\
.199 / .494\end{array}$ & $\begin{array}{l}6.91 / 7.09 \\
8.37 / 8.43 \\
5.75 / 5.88 \\
2.27 / 8.08\end{array}$ \\
\hline 2000 & $\begin{array}{l}\text { A) uminum } \\
\text { Nickel } \\
\text { Beryllitum- } \\
\text { copper } \\
\text { Graphite- } \\
\text { epoxy }\end{array}$ & 400.5 & $\begin{array}{c}0.789 / 0.877 \\
.916 / .925 \\
.886 / .908 \\
.616 / .868\end{array}$ & $\begin{array}{c}0.725 / 0.829 \\
.881 / .892 \\
.854 / .876 \\
.547 / .796\end{array}$ & $\begin{array}{r}0.160 / 0.120 \\
.087 \% .082 \\
.080 \% .080 \\
.172 \% .180\end{array}$ \\
\hline
\end{tabular}




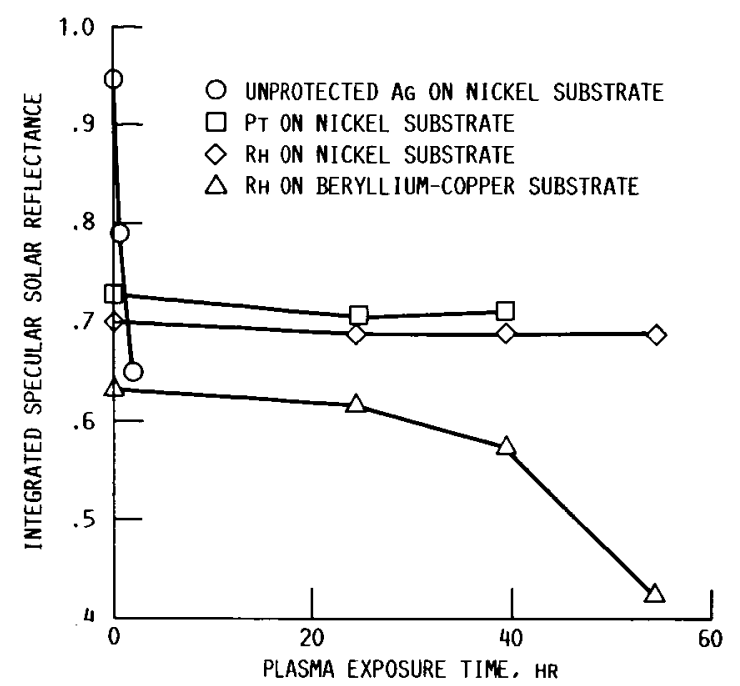

Figure 1. - INTEgRATEd SOLAR SPECULAR REFLECTANCE AS A FUNCTION OF ASHER PLASMA EXPOSURE TIME FOR
UNPROTECTED SILVER. PLATINUM, AND RHODIUM REFLECTING SURFACES.

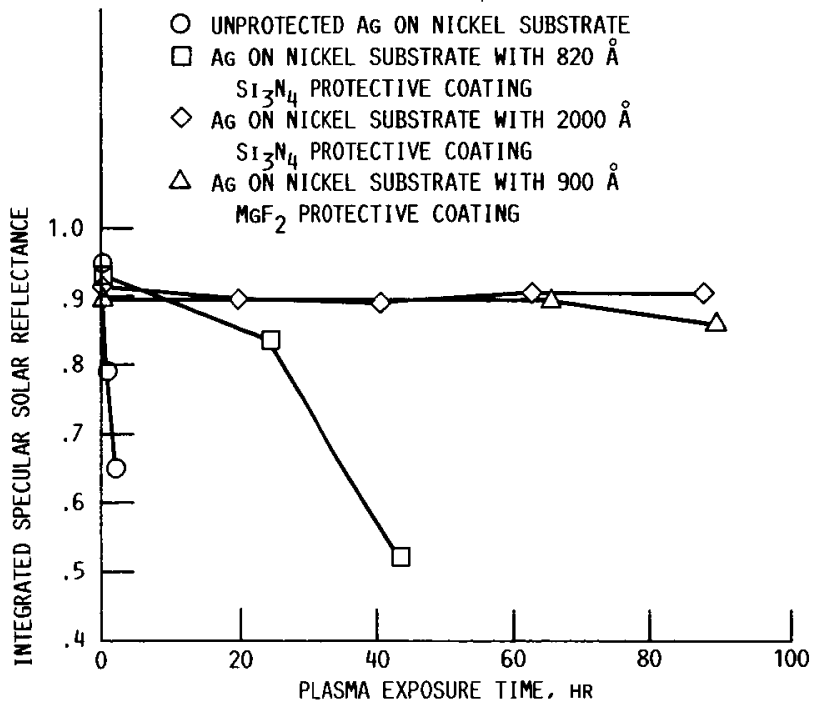

FIGURE 2. - INTEGRATED SOLAR SPECULAR REFLECTANCE AS A FUNCTION OF ASHER PLASMA EXPOSURE TIME FOR SILVER RE-
FLECTING SURFACES WITH AND WITHOUT PROTECTIVE COATINGS 


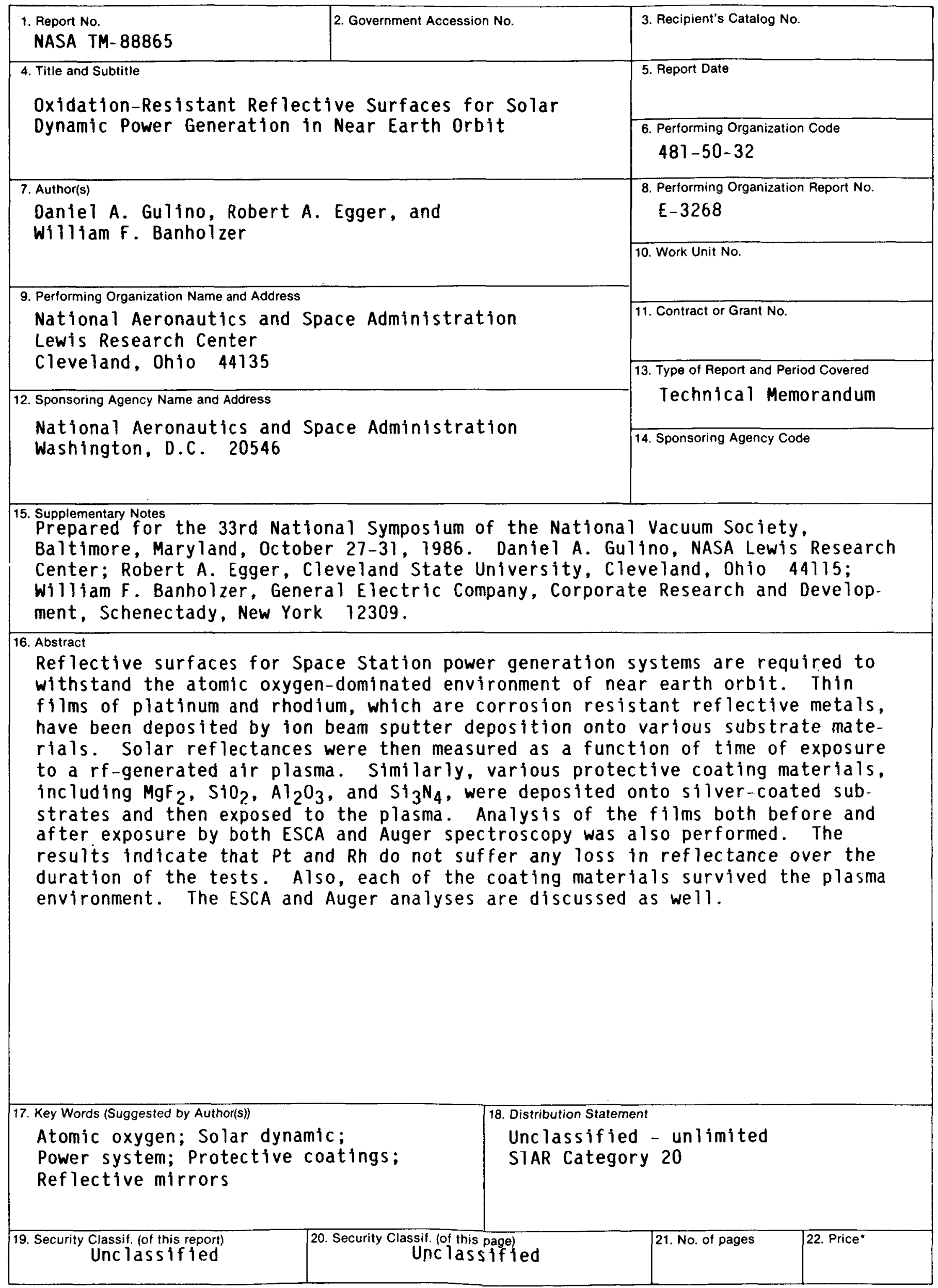

*For sale by the National Technical Information Service, Springfield, Virginia 22161 